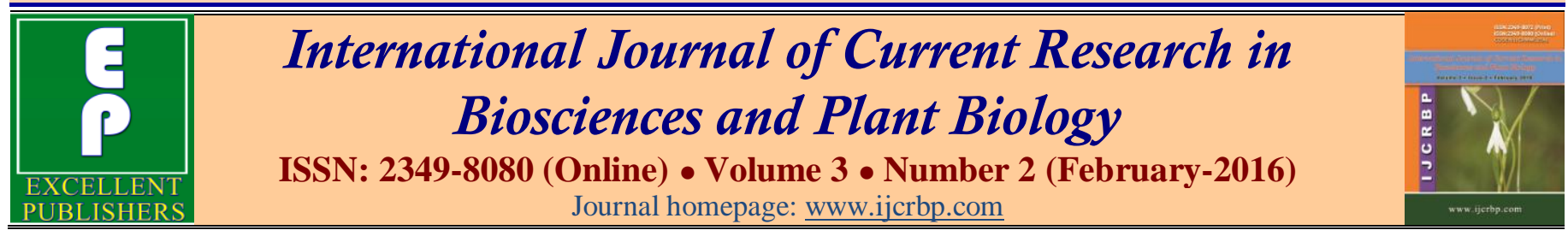

\title{
The Status of Mineral and Anti-Nutritional Composition of Raw and Fermented Seeds of African Locust Bean (Parkia biglobosa)
}

\author{
B. O. Abdulrahman*, M. Osibemhe and A. S. Idoko \\ Department of Biochemistry and Molecular Biology, Federal University Dutsin-Ma, Katsina State, Nigeria \\ *Corresponding author.
}

\begin{abstract}
A bstract
African Locust Bean (Parkia biglobosa) is among the leguminous plants used by man particularly in some African countries for the production of local condiment. This study sought to investigate the status of mineral and anti-nutritional compositions of raw and fermented seeds of African locust bean. The results indicated that fermentation significantly $(p<0.05)$ reduced the contents of the minerals examined except copper which had the same content $(0.02 \mathrm{mg} / \mathrm{kg})$ in both the raw and fermented seeds. The content of the anti-nutrients: tannins $(8.34 \mathrm{mg} / 100 \mathrm{~g})$, phytic acid $(41.77 \mathrm{mg} / 100 \mathrm{~g})$, and oxalate $(180.00 \mathrm{mg} / 100 \mathrm{~g})$ in the raw seeds were significantly reduced to $5.94 \mathrm{mg} / 100 \mathrm{~g}$, $6.41 \mathrm{mg} / 100 \mathrm{~g}$, and $70.00 \mathrm{mg} / 100 \mathrm{~g}$ in the fermented seeds respectively. Therefore, this present work showed that fermentation had influence in the mineral and anti-nutritional compositions of African locust bean.
\end{abstract}

\section{Article Info}

Accepted: 09 January 2016

Available Online: 06 February 2016

Ke ywords

African locust bean

Anti-nutrients

Condiment copper

Fermentation

\section{Introduction}

Parkia biglobosa is one of the 34 known species of the genus Parkia whose centre of origin is in South America. Parkia biglobosa commonly called African locust bean tree is known in Yoruba as Igba, or Irugba, in Hausa as Dorowa and in Igbo as Origili. Parkia biglobosa is consumed mainly because the fruit is rich in minerals and valuable protein (Odunfa, 1985). According to (Clampbell - Platt, 1980), the most popular form of consumption is in its traditional fermentation into dawadawa, a food condiment for seasoning traditional soups.

The presence of antinutritional factors in Parkia biglobosa and other legumes have hindered their use as source of protein. Processing of African locust bean seed into dawadawa gives the product not only its peculiar aroma which enhances the taste and smell of several traditional dishes but also results in reducing level of antinutrients and improving its digestibility and nutritional value (Odunfa, 1985; Omafuvbe et al., 2004). Fermented foods are foods which have been subjected to the action of micro- organisms or enzymes so that desirable biochemical changes cause significant modification to the food (Clampbell-Platt, 1987). Natural fermentation can produce important nutrients or eliminate anti-nutrients. However the information on how fermentation would affect the mineral and antinutrients of Parkia biglobosa remained scanty. The present study was carried out to evaluate the mineral and antinutritional contents of the raw Parkia biglobosa seed and its fermented seed.

\section{Materials and methods}

\section{Collection of sample}

Dried African locust bean seed were bought from farmers at a market in Jos East local government in 
Fobor Plateau State. The seeds were sorted out to remove bad ones. The seeds were then stored in a black polythene bag at room temperature until required for use.

\section{Chemicals}

All the chemicals used were of analytical grade.

\section{Fermentation of Parkia biglobosa seed}

The processing of the African locust bean seed to condiment was carried out according to the method of (Omafuvbe et al., 2004) with slight modifications. The raw seed was boiled for 12 hours with potash added to soften the cotyledons and left overnight in the boiling water. Excess water was drained off and the seeds were manually hulled by pounding in a wooden mortar. After hulling, the cotyledons were cooked again for 45 minutes. The water was drained off, and the seeds were spread in a basket lined with sack. It was then covered with trays, wrapped with clothes and allowed to ferment for four days to produce the condiment.

\section{Determination of mineral composition}

The following mineral elements $(\mathrm{Zn}, \mathrm{Fe}, \mathrm{Cu}, \mathrm{Mn}, \mathrm{Ca}$, $\mathrm{Mg}$, and K) were determined using the Atomic Absorption Spectrophotometer (Unicam969). The sample $(2 \mathrm{~g})$ was weighed and digested in mixture of concentrated $\mathrm{HNO}_{3}$ and perchloric acid in ratio 6:1 in a fume cupboard. Heating was continued until the solutions turned colorless. The solutions were transferred into a $50 \mathrm{ml}$ standard flask and diluted to mark with deionized water. Mineral content was then analyzed by using the Unicam 969 Absorption spectrometer.

\section{Determination of antinutritional content in the sample}

The antinutritional factors tannin and phytic acid were determined following the method of (Joslyn, 1970) whereas oxalate was determined using the method of (Munro and Basir, 1973).

Tannin content: The Tannin content was obtained by weighing $5 \mathrm{~g}$ of the ground sample and defatted using 5\% ethyl for 15 minutes. The Tannin in the defatted sample was then extracted with methanol and the absorbance was taken at $760 \mathrm{~nm}$.

Phytic acid content: Phytic content was estimated by weighing $5 \mathrm{~g}$ of the ground sample which was extracted with $0.5 \mathrm{~N} \mathrm{HCl}$. The phytate was precipitated and converted to Ferric hydroxide and soluble Sodium phytate by adding sodium hydroxide. $5 \mathrm{ml}$ of ammonium Molybdate solution was added to the precipitate followed by $1 \mathrm{ml}$ of hydroquinone, it was made up to $100 \mathrm{ml}$ mark, and left for 1 hour before the absorbance was taken at $640 \mathrm{~nm}$. The concentration of phytate was obtained using the standard curve.

Oxalate content: Oxalate content was determined by the method of Munro and Basir (1973). The Oxalate was extracted with dilute $\mathrm{HCl}$ at $80^{\circ} \mathrm{C}$ and treated with concentrated ammonia. Further treatment with calcium chloride solution precipitated calcium oxalate which was solubilized with hot $25 \%$ sulphuric acid and finally titrated with $0.05 \mathrm{~N}$ Potassium Permanganate.

\section{Statistical analysis}

Mean values of each variable were taken and standard error calculated for three (3) determinations. The student t-test was used to determine the significance between the raw and fermented seeds. Where $p$-value less than 0.05 , was considered significant.

\section{Results and discussion}

The results showing some mineral composition of raw and fermented seeds of Parkia biglobosa is presented in Table 1. With the exception of copper, all the minerals studied were significantly reduced $(p<0.05)$ by fermentation. Copper was not significantly $(p>0.05)$ affected by fermentation. The significant decrease of minerals could be attributed to leaching out of solid matter into the soaking water. Reduction in mineral content could also be caused by removal of hull portion which may contain some amounts of minerals.

Table 1. Some mineral composition of raw and fermented seeds of African locust bean $(\mathrm{mg} / \mathrm{kg}) *$ dry weight.

\begin{tabular}{lll}
\hline Minerals & Raw seed & Fermented seed \\
\hline Zinc & $0.29 \pm 0.04$ & $0.10 \pm 0.03$ \\
Iron & $0.33 \pm 0.03$ & $0.17 \pm 0.02$ \\
Copper & $0.02 \pm 0.01$ & $0.02 \pm 0.04$ \\
Manganese & $0.11 \pm 0.02$ & $0.03 \pm 0.01$ \\
Calcium & $2.66 \pm 0.10$ & $1.11 \pm 0.015$ \\
Magnesium & $2.64 \pm 0.11$ & $0.34 \pm 0.02$ \\
Potassium & $21.35 \pm 2.5$ & $15.49 \pm 2.00$ \\
\hline
\end{tabular}

*Values are means of triplicate determinations with standard error of mean. 
Calcium and magnesium are important minerals required for teeth and bone development in children. Potassium is an important mineral needed for normal muscle functioning.

Similar result was obtained by Olakunle and Adebola (2012) who reported slight decrease in potassium, phosphorus and magnesium during the fermentation of African locust bean to its condiment. This is also in agreement with Omodara and Olowomofe (2013) who recorded a reduction in the mean values of calcium, iron and magnesium of fermented African locust bean seed. Enujuigha and Akanbi (2005) reported a decrease in concentration of major minerals like potassium, calcium, zinc and iron during the fermentation of the oil bean seeds. The decrease in the level of minerals content with fermentation may be attributed to their utilization by the microorganisms involved in the fermentation process for their metabolic activities. According to Oladunmoye (2007), some minerals may be leached into the growth medium. The minerals are also used up by microbes as nutrient source.

Table 2 shows the antinutritional composition of raw and fermented seed of Parkia biglobosa. All the studied antinutrients were significantly reduced $(p<0.05)$ by fermentation. Fermentation caused $29 \%, 85 \%$ and $61 \%$ reductions in the levels of tannin, phytic acid and oxalate respectively

Table 2. Antinutritional composition of the raw and fermented African locust Bean seed (mg/100g)* dry weight.

\begin{tabular}{lll}
\hline Antinutrients & Raw seed & Fermented seed \\
\hline Tannin & $8.34 \pm 0.11$ & $5.94 \pm 0.01$ \\
Phytic Acid & $41.77 \pm 0.31$ & $6.41 \pm 1.50$ \\
Oxalate & $180.00 \pm 1.15$ & $70.00 \pm 0.93$ \\
\hline \multicolumn{2}{l}{ *Values are means of triplicate determinations with standard } \\
error of mean.
\end{tabular}

Phytates molecule is negatively charged at the physiological $\mathrm{pH}$ and is reported to bind essential nutritionally important divalent cation such as $\mathrm{Fe}, \mathrm{Zn}$, $\mathrm{Mg}$, and $\mathrm{Ca}$. This forms insoluble complexes thereby making mineral unavailable for absorption (Siddhuraju and Becker, 2001). Oxalates are known to form insoluble complexes with most minerals such as iron, phosphorus and calcium thus reducing their bioavailability (Osagie and Eka, 1998). Tannins form insoluble enzyme resistance complex with proteins thereby reducing their digestibility and protein quality. Tannin causes decreased feed consumption in animals, binds dietary protein and digestive enzymes to form complexes that are not readily digestible (Aletor, 1993). They also cause decreased palatability and reduced growth rate (Roeder, 1995).

These reduction in antinutrients may be attributed to the processing techniques involved in the fermentation of the raw African locust bean seed which include dehulling, soaking, boiling which helps to leach away antinutrients. This finding is in agreement with other researchers (Esenwah and Ikenebomeh, 2008; Ijarotimi and Keshinro, 2012). Adegbehinde et al. (2012) recorded a similar result during the fermentation of lima bean. This confirms an earlier suggestion that the traditional methods employed in processing the seeds namely soaking, hydrothermal treatment, and fermentation would considerably reduce the levels of antinutritional factor (Enujiugha and Ayodele-Oni, 2003).

\section{Conclusions}

It is evident from this study that the African locust bean seed is rich in some essential minerals particularly potassium. The study has also shown the presence of some antinutritional factors such as oxalate, phytate and tannin in African Locust bean seed. In addition, the study has revealed that different processing techniques of African locust bean seed could reduce the level of antinutrients present. The study also brought to light that fact that fermentation reduces significantly antinutritional factors in African locust bean seed. Thus African locust bean seed may serve as a cheap source of protein and minerals if appropriate processing techniques such as soaking, dehulling, boiling and fermentation are applied.

\section{Conflict of interest statement}

Authors declare that they have no conflict of interest.

\section{References}

Akbar Adegbehingbe, K.T., Adetuyi A.A., Akinyosoye F.A., 2014. Effect of fermentation on nutrient content of cooked-ground lima bean (Phaseolus lunatus) seeds using Bacillus subtilis and Bacillus pumilus. Brit. Microbiol. Res. J. 4(11), 1285-1298.

Aletor, V.A., 1993. Allelochemicals in plant food and feeding stuffs (1) nutritional, biochemical and physiopathological aspects in animal production. J. Vet. Hum. Toxicol. 35(1), 57-67.

Campbell-Platt, G., 1987. Fermented Foods of the World. A Dictionary and Guide. Butterworth Heinemann. 
Clampbell-Platt, G., 1980. African locust bean (Parkia species) and its West African fermented food products, dawadawa. Ecol. Food Nutr. 9, 123-132

Enujiugha, V.N., Akanbi, C.T., 2005. Compositional changes in African oil bean (Pentaclethra macrophylla Benth.) seeds during thermal processing. Pak. J. Nutr. 27-31.

Enujuigha, V.N., Ayodele O., 2003. Evaluation of nutrients and some antinutrients in lesser known under-utilized oil seeds. Int. J. Food Sci. Tec. 38, 525-528

Esenwah, C.N., Ikenebomeh, M.J., 2008. Processing effects on the nutritional and anti-nutritional contents of African locust bean (Parkia biglobosa Benth.) seed. Pak. J. Nutr. 7 (2), 214-217.

Ijarotimi, O.S., Keshinro, O.O., 2012. Comparison between the amino acid, fatty acid, mineral and nutritional quality of raw, germinated and fermented African locust bean (Parkia biglobosa) flour. Acta Sci. Pol., Technol. Aliment. 11(2), 151-165

Joslyn, N., 1970. Methods in Food Analysis: Physical, Chemical and Instrumental Methods of Analysis. $2^{\text {nd }}$ Edn. Academic Press, New York. pp.708-720.

Munro, A., Basir O., 1973. Oxalate in Nigeria vegetables. W. Afri. J. Biol. Appl. Chem. 12, 14-18.

Odunfa, S. A., 1985. African fermented foods. In: Microbiology of Fermented Foods (Ed.: Wood, B.J.B.). Vol. 11. Amsterdam, Elsevier Applied Science Publishers. pp.155-191.
Oladunmoye, M.K., 2007. Effect of fermentation on nutrient enrichment of locust beans (Parkia biglobosa). Res. J. Microbial. 2, 185-189.

Olakunle, M.M., Adebola, A., 2012. Effect of natural fermentation on nutritive value and mineral composition of African Locust Bean. Pak. J. Nutr. 11(1), 11-13

Omafuvbe, B.O., Falade, O.S., Osuntogun, B.A., Adewusi, S.R.A., 2004. Chemical and biochemical change in African locust beans (Parkia biglobosa) and melon (Citrullus vulgaris) seeds during fermentation to condiments. Pak. J. Nutr. 3, 140-145.

Omodara, T.R., Olwomofe, T.O., 2013. Effect of fermentation on the nutritional quality of African locust bean and soya bean. Int. J. Sci. Res. 2319-7064.

Osagie, A.U., Eka, O.U., 1998. Nutritional Quality of Plant Foods. Published by Post-harvest Research Unit, Department of Biochemistry, University of Benin, Nigeria. pp.1-21.

Roeder, E., 1985. Medicinal plants in Europe containing pyrrolizidine alkaloids. Pharmazie. 50, 83-98.

Siddhuraju, P., Becker, K., 2001. Effect of various indigenous processing methods on galactoside and mono and disaccharide content of an Indian tribal pulse (Mucuna prueriens var. utilis). J. Sci. Food Agric. 81, 718-725.

\section{How to cite this article:}

Abdulrahman, B. O., Osibemhe, M., Idoko, A. S., 2016. The status of mineral and antinutritional composition of raw and fermented seeds of African locust bean (Parkia biglobosa). Int. J. Curr. Res. Biosci. Plant Biol. 3(2), 1-4.

doi: http://dx.doi.org/10.20546/ijcrbp.2016.302.001 